\title{
INNOVATION OF THE GREEN ECONOMY
}

Katarzyna Brodzinska ${ }^{1}$, PhD habilitated; Zbigniew Brodzinski², PhD habilitated

${ }^{1}$ Departament of Agrotechnology, Agricultural Production Management and Agribusiness, University of Warmia and Mazury in Olsztyn, Poland; '2Department of Environmental Economics, Real Estate and Agribusiness, University of Warmia and Mazury in Olsztyn

Abstract. The innovativeness of the green economy can be considered both in relation to total innovation and eco-innovation. The aim of the research is to assess the level of innovation of enterprises operating in the green economy sectors, with particular emphasis on eco-innovation. The research was carried out in 2017, using CATI (Computer Assisted Telephone Interviewing) technology, among 578 randomly selected enterprises of the SME sector directly related to the green economy, located in the Warminsko-Mazurskie Voivodeship. The analyzes were carried out in relation to data on innovativeness of enterprises collected by the Central Statistical Office and Eurostat data regarding the development of this sector in EU countries.

The analyses show that the level of innovativeness of companies in the green economy sector in the WarminskoMazurskie Voivodship is low and process innovations are the ones that are most often introduced which are related to the search for resource-efficient production technologies and services (eco-innovation). Authors' research and literature review indicate that there are No universal recipes for increasing innovation and competitiveness of economies; however, the high level of innovation, including eco-innovativeness is characterized by the economies of countries that invest in research and development, human and social capital and mobilize various institutions around common purposes.

Key words: green economy, innovation, eco-innovation.

JEL code: R11, R58.

\section{Introduction}

The "green economy" in recent years has become synonymous with the necessary changes related to the search for new directions of economic development including ecological aspects, and in particular the so-called low-emission technologies (Green Growth 2017, Gorka Luszczyk 2014, Unmünßig 2012). It is not only about the reduction of gas and pollution emissions, but also about increasing the efficiency of energy and raw materials use, protecting biodiversity and the ecosystem, while increasing income and employment. In this context, the ability of green economy enterprises to implement innovative solutions is particularly important.

The aim of the research is to assess the level of innovation of enterprises operating in the green economy sectors in the Warminsko-Mazurskie Voivodeship. The research was carried out in 2017, using CATI (Computer Assisted Telephone Interviewing) technique, among 578 randomly selected enterprises of the SME sector directly related to the green economy, including those engaged in agrifood processing, provision of services, production and rural tourism (according to the PKD section). The size of the research sample was calculated using the following formula:

$$
n_{b}=\frac{N}{1+\frac{4 d^{2}(N-1)}{z_{\alpha}^{2}}}
$$

where:

$n$ - size of the research sample, $N$ - population size,

$d$ - margin of error, $z$ - critical value for the confidence level.

A confidence coefficient of at least $95 \%$ was assumed and a maximum estimation error of not less than $5 \%$. Survey research concerned the assessment of innovativeness of enterprises in the green economy sector according to the areas of their economic activity.

\footnotetext{
${ }^{1}$ Corresponding autor tel.: 48895233923; E-mail address: katarzyna.brodzinska@uwm.edu.pl

${ }^{2}$ Corresponding autor: E-mail address: zbr@uwm.edu.pl
} 
The research hypothesis assumes that enterprises in the green economy sector are innovative. Own research was analysed in relation to data on innovativeness of enterprises collected by the Central Statistical Office in Poland, which allowed to evaluate the innovative activity at the level of individual voivodships. In the international context, the Eurostat secondary statistics on selected green growth indicators and data collected by the Eco-Innovation Observatory were analysed.

\section{Research results and discussion Determinants of green growth}

The concept of green economy, as a pragmatic approach to the implementation of sustainable development, implemented by EU countries brings tangible results. The Eurostat data shows that green sectors generate increasingly more turnover and create more jobs because they are labourintensive (e.g. organic farming).

Sectors included in the green economy include in particular renewable energy, low-emission transport, energy-efficient construction, clean technologies, improvement of waste management, sustainable agriculture, forestry fishing (Hamdouch and Depret 2010, UNEP 2011), but in fact virtually all areas of human activity can be included here that affect the natural environment in any way. The background to the deliberations on the possibilities of stimulating green growth is the innovative activity in the broad sense of innovation, as well as in relation to eco-innovations, which have a beneficial effect on economic development, environmental protection and create the foundations of sustainable development. Their introduction is supported by business, social and environmental factors (Romanczyk 2010, Wegrzyn 2013). Five types of eco-innovations are the most common in the literature: technological eco-innovations (products and production processes), social eco-innovations (behaviour change, consumption habits), organizational eco-innovations (ecoaudits), institutional eco-innovations (cooperation platforms, informal groups, networks established to deal with environmental issues), marketing eco-innovations (eco-labels) (Sinclair-Desgagne et al., 2003).

Among the EU countries, Scandinavian countries as well as Germany and Luxembourg have the highest ability to build eco-innovation. According to Eco-Innovation Observatory data1, in 2017 Ecoinnovation index was Sweden - 144, Finland - 141, Germany - 139, Luxembourg 139. Latvia in this ranking was on the 22 nd position (eco-innovation index - 73), and Poland in the 26th position (59), ahead of Cyprus (45) and Bulgaria (38) (Eco-innovation ...). The high level of eco-innovation of the Scandinavian countries results mainly from high expenditures on eco-innovations, undertaken activities, achieved results, and in the case of Sweden, also achieved environmental effects. In countries with low eco-innovativeness ratios such as Poland and Latvia, the area of socio-economic effects and achieved results is the strongest (Fig. 1).

\footnotetext{
${ }^{1}$ Eco-innovation at the heart of European policies https://ec.europa.eu/environment/ecoap/indicators/index_en Access 28.01.2019
} 


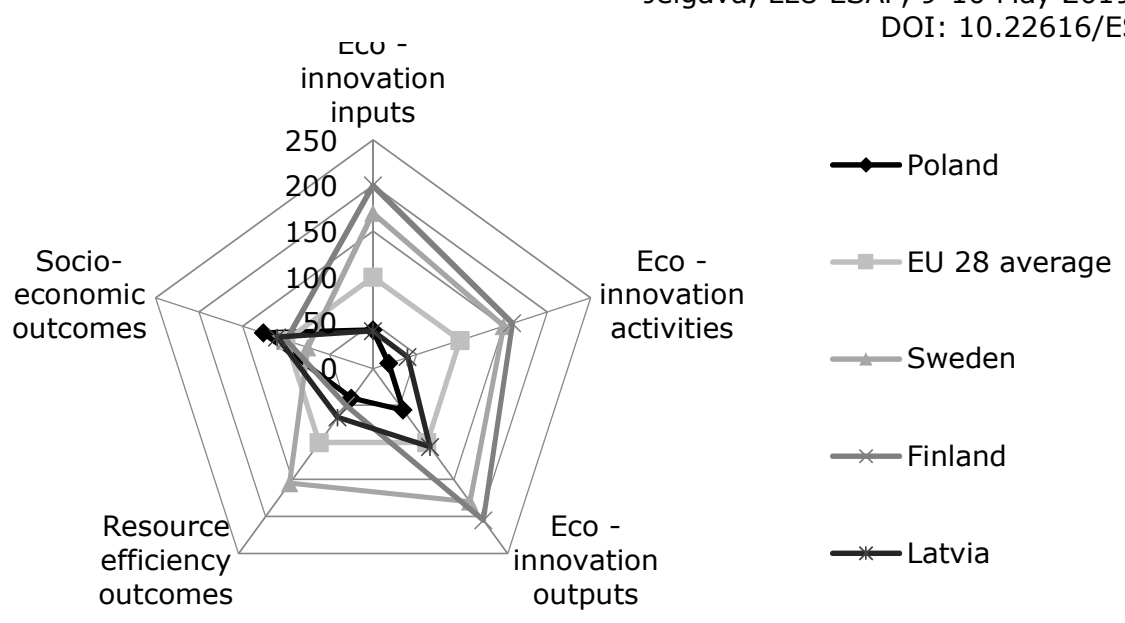

Source: Data of Eco-Innovation Observatory

(https://ec.europa.eu/environment/ecoap/indicators/index_en Access. 25.01.2019.)

\section{Fig. 1. Eco-innovativeness index (5 areas) in selected EU countries}

The unfavourable position of Poland in the ranking may result from many factors, including among others financial barriers on the part of entrepreneurs and consumers, low level of awareness in the scope of benefits resulting from the implementation of ecological innovative technologies or low expenditure on R\&D (Kulyk, Gasiorek-Kowalewicz, 2018). The analysis of expenditures incurred for research and development in the years 2002-2016 indicates that the greatest potential for innovation development is created in Sweden, and the important aspect of it is that the level of expenditure has been maintained in this country at a high level since 2002 and is gradually increasing. In turn, in Finland, expenditures on research and development activities were at a lower level in this period, and since 2011 they have been showing a downward trend. Poland in this ranking is ranked 20th among the 28 countries of the European Union. Despite the observed trend of successive expenditure growth from USD 73.7 per capita in 2002 to USD 264 in 2015 (No data for 2016), this is a relatively low amount, although still much higher than e.g. in Latvia ( 113 USD) (Tab. 1).

The process of economic changes aimed at increasing resource efficiency, improving efficiency and minimizing the negative impact of economic activities on the natural environment requires, as already mentioned, adequate financial outlays for research and development and time. On the one hand, it is about the time that is needed to develop pro-environmental technologies and, on the other, the re-evaluation of priorities in which environmental protection will be as important as the company's financial result. The low level of expenditure on research and development in Poland is accompanied by a low level of innovation in the economy. 
Gross domestic expenditure in research and development activity (R\&D) - per capita (USD)

\begin{tabular}{|c|c|c|c|c|c|c|c|c|}
\hline \multirow{2}{*}{ Country } & 2002 & 2010 & 2011 & 2012 & 2013 & 2014 & 2015 & 2016 \\
\hline & \multicolumn{7}{|c|}{ USD per capita } & \\
\hline Sweden & 1161 & 1339 & 1422 & 1468 & 1510 & 1464 & 1564 & 1592 \\
\hline Austria & 644 & 1147 & 1187 & 1355 & 1417 & 1498 & 1523 & 1559 \\
\hline Denmark & 748 & 1256 & 1308 & 1336 & 1389 & 1396 & 1440 & 1408 \\
\hline Germany & 716 & 1084 & 1194 & 1250 & 1276 & 1353 & 1395 & 1439 \\
\hline Luxembourg & 871 & 1286 & 1343 & 1165 & 1241 & 1276 & 1304 & 1269 \\
\hline Finland & 931 & 1445 & 1480 & 1389 & 1357 & 1314 & 1218 & 1191 \\
\hline Belgium & 576 & 822 & 893 & 968 & 1021 & 1068 & 1124 & 1159 \\
\hline Netherlands & 601 & 768 & 877 & 906 & 951 & 973 & 993 & 1027 \\
\hline France & 621 & 784 & 821 & 840 & 885 & 914 & 920 & 930 \\
\hline Ireland & 372 & 690 & 701 & 730 & 763 & 786 & 831 & 853 \\
\hline United Kingdom & 470 & 599 & 613 & 604 & 648 & 678 & 796 & 720 \\
\hline Slovenia & 292 & 571 & 698 & 744 & 769 & 730 & 691 & 655 \\
\hline Czech Republic & 200 & 369 & 448 & 518 & 579 & 637 & 646 & 583 \\
\hline Italy & 311 & 425 & 435 & 454 & 469 & 484 & 491 & 493 \\
\hline Estonia & 82.7 & 341 & 565 & 551 & 473 & 414 & 428 & 381 \\
\hline Spain & 234 & 431 & 425 & 412 & 414 & 417 & 425 & 432 \\
\hline Portugal & 147 & 419 & 390 & 365 & 370 & 371 & 367 & 388 \\
\hline Hungary & 143 & 246 & 272 & 292 & 340 & 345 & 357 & 322 \\
\hline Slovakia & 74.9 & 153 & 171 & 215 & 230 & 255 & 347 & 241 \\
\hline Poland & 73.7 & 150 & 168 & 207 & 213 & 238 & 264 & b.d. \\
\hline Greece & 11.7 & 169 & 176 & 177 & 212 & 224 & 258 & 266 \\
\hline Latvia & 41.2 & 107 & 138 & 141 & 139 & 164 & 153 & 113 \\
\hline Rumania & 27.1 & 77.65 & 89.2 & 91.6 & 76.8 & 78.8 & 105 & 111 \\
\hline Bulgaria & $?$ & n.d. & n.d. & n.d. & n.d. & n.d. & n.d. & n.d. \\
\hline Croatia & $?$ & n.d. & n.d. & n.d. & n.d. & n.d. & n.d. & n.d. \\
\hline Cyprus & $?$ & n.d. & n.d. & n.d. & n.d. & n.d. & n.d. & n.d. \\
\hline Lithuania & $?$ & n.d. & n.d. & n.d. & n.d. & n.d. & n.d. & n.d. \\
\hline Malta & $?$ & n.d. & n.d. & n.d. & n.d. & n.d. & n.d. & n.d. \\
\hline
\end{tabular}

Source: http://stat.gov.pl/statystyka-miedzynarodowa/porownania-miedzynarodowe/tablice-o-krajach-wedlugtematow/nauka-spoleczenstwo-informacyjne-innowacyjnosc/ (Access: 25.01.2019) Explanation: n.d. - No data.

\section{Innovation of enterprises in Poland}

Large diversification of the level of innovation in the economy in Poland (Fig. 2) may result from the so-called contextual conditions that have a significant impact on the ability of enterprises to undertake innovative activities. The most important factors include the settlement network, population density, as well as the natural conditions that create material and non-material components of enterprises and their ability to create innovative solutions (Brodzinski, Brodzinska, 2018). It is also worth emphasizing that innovations are rarely found in isolation, it is a highly interactive process of cooperation between companies most often through partnership, alliances and joint ventures with external entities or by concluding contracts for conducting R\&D works or purchasing a license. The cooperation most often includes research institutes, universities, consulting companies, private R\&D institutions, other companies belonging to the same group of enterprises (Weresa 2014, Kisielnicki, 2016). 
In the innovation ranking covered by the research, the Warminsko-Mazurskie Voivodeship is on the last position. This applies to both the percentage of innovation-active industrial and service enterprises as well as the share of revenues from the sale of new or significantly improved products in the value of total sales revenues, which is also the lowest in the country. Low innovativeness of the economy in the Warminsko-Mazurskie Voivodeship can be explained by the low level of socioeconomic development and the low share of industrial enterprises. The cooperation of enterprises in the field of innovative activity is related to the size of the enterprise, i.e. the larger the enterprise, the more often it cooperates in the field of innovative activity. The percentage of large industrial enterprises (250 and more people) that cooperated in innovative activities was almost three times higher than smaller enterprises (from 10 to 49 employees). In relation to the above, it is obvious that the regions in which large industrial enterprises dominate are higher in the innovation ranking.
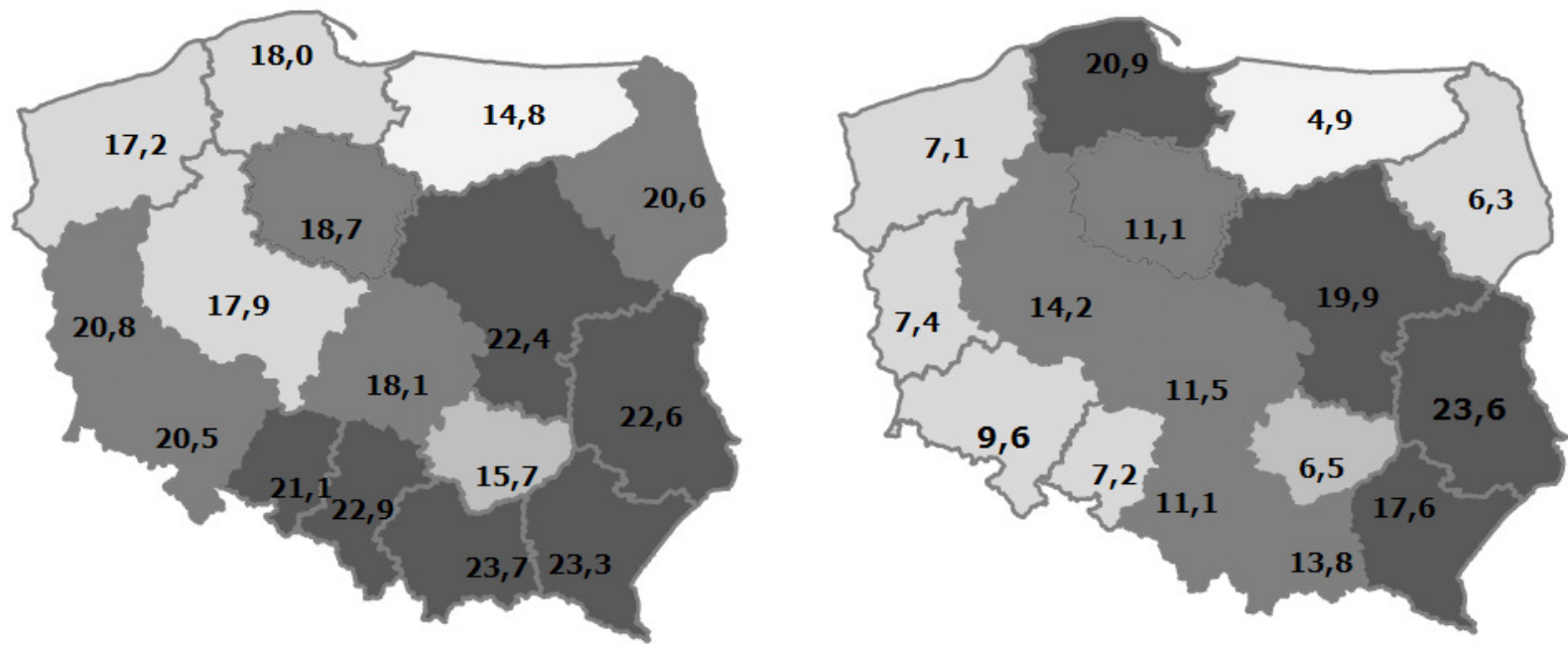

Source: Innovative activity of enterprises in years 2014-2016 p. 20

https://stat.gov.pl/files/gfx/portalinformacyjny/pl/defaultaktualnosci/5496/2/15/1/dzialalnosc_innowacyjna_ przedsiebiorstw_w_latach_2014-2016.pdf Access. 04.02.2019.

Fig. 2. Industrial and service innovation active enterprises in the years 2014-2016 by voivodships ( \%)

\section{Barriers to innovation in enterprises in the green economy sector - results of authors' research}

The low level of innovativeness of the economy in the Warminsko-Mazurskie Voivodeship is reflected in the results of research conducted among entities included in the green economy in the rural areas of this region. As it was observed, the general trend of the surveyed companies was passivity in the area of innovation implementation, as many as $78.4 \%$ of enterprises did not introduce any innovative solutions. The low level of innovation of companies included in the green economy may indicate their more traditional approach to the issue of resource management and a lower competitive position in this respect. It is also worth emphasizing that in the future this may lead to the deepening of the differences in the development of green economy in individual regions of the country.

Among the enterprises that declared the implementation of innovations, the ones that noticed were: product, process, and organizational innovations (Olso Manual). Product innovations which are understood as the introduction of a new product or service or its significant improvement. Innovations in the production processes of a product / service were most often introduced to reduce production or delivery costs, increase quality, increase production efficiency. In turn, organizational innovations were perceived most often as a certain additional element or as solutions ensuring adaptation of technical and technological innovations in the enterprise. However, it is worth 
emphasizing that in recent years, the entrepreneurs' approach to organizational innovations has changed and is also treated as a significant source of growth in the efficiency of the company's operations. This applies to a large extent to companies from the SME sector, which in the category of low-cost organizational innovations may perceive important opportunities and opportunities for development (Lachiewicz, 2014).

Observed tendency regarding the low level of activity in the field of innovation implementation by the enterprises of the green economy operating in rural areas of the Warminsko-Mazurskie Voivodeship that were covered by the research concerned basically all enterprises - regardless of their area of economic activity. The percentage of enterprises that have not been active in the field of innovation implementation, ranged from $64.2 \%$ in manufacturing enterprises to $80.2 \%$ in service enterprises.

Production companies (including those producing wooden products, furniture, boilers, etc.) most often implemented innovations in the field of modernization of product manufacturing processes (20.0 \%) and product innovations (18.3\%) (tab.2). In enterprises from the renewable energy sector, mainly process innovations aimed at improving energy storage systems were introduced. Renewable energy is the least sTable source of energy, and it is the potential interruptions in its supply that are the biggest problem of this sector in the dissemination of renewable energy. In the enterprises from agri-food processing covered by the research, $21.4 \%$ of enterprises implemented innovative solutions, which included both product and process innovations ( $14.3 \%$ each).

In the tourism industry which is very important for the region covered by the research, 20,5\% of enterprises implemented innovative solutions. The changes introduced most often had the character of product innovations (12.8\%), less frequently process (7.7 \%). To a small extent, they concerned modern solutions in the scope of work organization (5.4\%) and customer service (5.1\%). From the point of view of the tourism sector, strong competition and the need to adapt companies to changing conditions requires undertaking frequent innovative actions. It must be remembered that an important aspect of innovation as a factor of competitiveness is their social usefulness. Better satisfaction of the needs and expectations of the modern tourist translates into achieving better efficiency of tourist activities (Mielcarek, Szalczyk, 2013).

The low level of innovation in the tourism industry in the region as attractive as the WarminskoMazurskie region is difficult to explain in principle. The level of innovation of other service enterprises was close to the tourism industry and was at the level of $19.8 \%$. Most often, enterprises in this industry introduced innovations in the scope of a new service, as a product ( $8.8 \%)$ and work organization (7.3\%). Few introduced innovations regarding service delivery processes (5.2\%) and customer service (4.9).

Table 2

Types of innovations according to areas of economic activity of enterprises [\%]

\begin{tabular}{|l|c|c|c|c|c|}
\hline \multicolumn{1}{|c|}{ Specification } & $\begin{array}{c}\text { Agri-food } \\
\text { processing }\end{array}$ & $\begin{array}{c}\text { Service- } \\
\text { providing }\end{array}$ & Production & $\begin{array}{c}\text { Renewable } \\
\text { energy } \\
\text { sources }\end{array}$ & Tourism \\
\hline Product innovation & 14.3 & 8.8 & 18.3 & 0.0 & 12.8 \\
\hline Process innovation & 14.3 & 5.2 & 20.0 & 25.0 & 7.7 \\
\hline Organizational innovation & 0.0 & 7.3 & 5.8 & 0.0 & 5.1 \\
\hline $\begin{array}{l}\text { The company didn't introduce } \\
\text { innovation }\end{array}$ & 78.6 & 80.2 & 64.2 & 75.0 & 79.5 \\
\hline
\end{tabular}

Source: authors' research 


\section{Conclusions, proposals, recommendations}

There are No universal recipes for increasing innovation and competitiveness of economies. However, it is known that the economies of the countries which are at a high level of innovativeness, attach great importance to improving the efficiency of public administration, invest in human and social capital and mobilize various institutions around common goals. The system of financing research and development activities as well as cooperation between industry and research centres plays a large role in this respect.

The percentage of companies in the green economy sector surveyed in the Warminsko-Mazurskie Voivodeship which implement innovative solutions ranged from $19.8 \%$ (service companies) to $25 \%$ (RES enterprises). The low level of innovativeness of these companies, regardless of the areas of economic activity may indicate the traditional way of their management and low innovation potential of these companies. Therefore, there is a justified concern that this may lead to further deepening of the differences in the ability to create innovative solutions in the green economy in the region covered by research in relation to other regions of Poland.

\section{Bibliography}

1. Brodzinska, K., Brodzinski, Z. (2018). The Role of Environment in Stimulating the Development of Green Economy. Proceeding of the 2018 International Conference "Economic Science for Rural Development" NO 49, Jelgava, LLU ESAF, DOI 10.22616/ESRD.2018.114, pp. 25-31.

2. Eco-innovation at the Heart of European Policies https://ec.europa.eu/environment/ecoap/indicators/index_en Access 28.01.2019

3. Gorka, K., Luszczyk, M. (2014). Green Economy and Knowledge-based Economy and Sustainable Development. Optimum. Studia ekonomiczne 3 (69)

4. Green Growth Indicators (2017). OECD Green Growth Studies, Paris https://read.oecdilibrary.org/environment/green-growth-indicators-2017_9789264268586-en Access 24.01.2019

5. Hamdouch, A., Depret, M.H. (2010). Policy Integration Strategy of the "Green Economy": Foundations and implementation patterns. Journal of Environmental Planning and Management, vol. 53, issue 4, pp. 473490.

6. Innovative Activity of Enterprises in years 2014-2016. GUS, Warszawa-Szczecin 2017 https://stat.gov.pl/files/gfx/portalinformacyjny/pl/defaultaktualnosci/5496/2/15/1/dzialalnosc_innowacyjna _przedsiebiorstw_w_latach_2014-2016.pdf, Access. 04.02.2019.

7. Kisielnicki, J. (2016). The Innovativeness of Polish Economy on the Background of Selected Countries of the European Union and the World, Studia Ekonomiczne, Zeszyty Naukowe Uniwersytetu Ekonomicznego w Katowicach (281) pp.67-79.

8. Kulyk, P.,Gasiorek-Kowalewicz, A. (2018). Development of the Green Economy on the Example of the Visegrad Group, Zeszyty Naukowe SGGW, Problemy Rolnictwa Swiatowego, t. 18 (XXXIII)(2), pp. 193-206.

9. Lachiewicz, S. (2014). Organizational Innovations in Small and Medium Enterprises, Studia Ekonomiczne (183) pp. 153-161.

10. Mielcarek, B., Szalczyk, A. 2013. Innovation as a Factor of Competitiveness of the Tourist Sector in the Conditions of Globalization in: Contemporary Conditions and Problems of Tourism Development. Pawlusinski R. (ed.), IGiGP UJ, Kraków: pp. 199-206.

11. Oslo Manual, Rules for collecting and interpreting innovation data, Ed. Eurostat/OECD, 2008 http://www.nauka.gov.pl/mn/_gAllery/43/46/43464/20081117_OSLO.pdf Access 25.01.2018

12. Romanczyk, A. (2010). Eco-innovations, PARP, Warszawa

13. Sinclair-Desgagne, D. Feigenbaum, É. Pawlak, The Integrated Product Policy and the Innovation Process: An Overview, Scientifc Series, CIRANO, Montréal 2003.

14. UNEP (2011). Towards a Green Economy: Pathways to Sustainable Development and Poverty Eradication. New

15. Unmünßig, B., W, Sachs, T. Fatheuer (2012). Critique of the Green Economy Toward Social and Environmental Equity, Vol. 22. Heinrich Böll Foundation https://us.boell.org/sites/default/files/downloads/Critique_of_the_Green_Economy.pdf. Access 25.01.2019

16. Wegrzyn, G. 2013. Innovation as a determinant of structural changes in the labour market in: Economic Systems and their Evolution: Macro- and Meso-economic Aspects. Studia Ekonomiczne Uniwersytetu Ekonomicznego w Katowicach Economic Studies at the University of Economics, Katowice, 145: pp. 211212.

17. Weresa, M. (2014). Innovative Policy, WN PWN, Warszawa. 